\title{
Anders Chydenius i finländsk och svensk historieforskning och historie- skrivning från 1800-talet till i dag
}

\author{
EN KÄND MEN OCKSÅ OKÄND MÅNGKAMPARE INOM \\ UPPLYSNING OCH POLITIK
}

Om upplysningsmannen och kyrkoherden Anders Chydenius (I729I803) har det skrivits och sagts väldigt mycket på olika forum under de senaste drygt 150 åren, inte minst därför att hans skriftliga produktion är både omfattande och mångsidig. Eli F. Heckscher (I879-I952), som utvecklade och bröt ny mark inom svensk ekonomisk historia, skrev på sin tid,lämpligt inför Chydenius 200-årsjubileum I929 i sin artikel om Chydenius i Svenskt biografiskt lexikon att denne under sin första riksdag I765-I766 skrivit ett "häpnadsväckande" antal olika skrifter. ${ }^{1}$ Det är lätt att hålla med Heckscher. Chydenius Samlade skrifter som gavs ut på svenska och finska och delvis också på engelska 20I2-20I6 konkretiserar detta. ${ }^{2}$

Artikeln är skriven inom ramen för forskningsprojektet "Yhteinen menneisyys, erilaiset tulkinnat. Bibliometrinen ja kvalitatiivinen analyysi varhaismodernista Ruotsin valtakunnasta Ruotsin ja Suomen historiografiassa I860-2020" (Hirsu), som utförs vid Jyväskylä universitet och finansieras av Konestiftelsen, https://www.jyu.fi/hytk/fi/ laitokset/hela/tutkimus/keskittymat/hirsu (hämtad 3/9 20I9).

I. Eli F. Heckscher, "Anders Chydenius", Svenskt biografiskt lexikon. Bd 8, Cederhielm-Cornelius, Stockholm: Bonniers 1929, https://sok.riksarkivet.se/Sbl/ Presentation. aspx?id=I4849 (hämtad 28/10 2018).

2. Anders Chydenius, Samlade skrifter. Band I-5. Utgivna av Maren Jonasson och Pertti Hyttinen, SSLS 762:I-5, Helsingfors: SLS \& Stockholm: Atlantis 2012-2016. Det sammanlagda sidantalet i Samlade skrifter är ca 3 ooo trycksidor. I varje volym finns därtill textkommentarer till varje Chydeniustext, skrivna av de främsta experterna inom respektive ämnesområde. Sammantaget uppgår kommentartexterna till ca 350 sidor och motsvarar därmed längden på en gedigen biografi. Samlade skrifter finns även tillgängliga på adressen http://chydenius.kootutteokset.fi/?lang=sv. 
I karakteristiker över Chydenius nämns nästan alltid hur ung han var (35 år) när han första gången deltog i riksdagen och hur långt nere i den kyrkliga hierarkin han befann sig som komminister i Nedervetils kapellförsamling. I det hierarkiska prästeståndet var bland andra biskoparna självskrivna som representanter för sitt stift, vilket innebar att antalet representanter från de lägre nivåerna i hierarkin ofta var litet och deras inflytande obetydligt. När man ser till antalet ledamöter hade prästeståndet den lägsta representationen vid ståndsförsamlingen, vilket gav aktiva och duktiga riksdagsledamöter förhållandevis goda möjligheter att påverka. Därför var det relativt sett lättast uttryckligen för ledamöterna i prästeståndet att inta platser i de frihetstida deputationerna och utskotten. Chydenius insatser i samband med den viktigaste riksdagen under frihetstiden, riksdagen I765-1766, har därför med skäl lyfts fram. Hans kraftiga insatser för att upphäva det bottniska handelstvånget, återkalla riksrådets rätt att sköta statsfinanserna och genomdriva världens första tryckfrihetsförordning var - och är - häpnadsväckande bedrifter. Trots detta uteslöts den arga unga mannen under sin första riksdag till slut ur sitt stånd, eftersom han i sin skrift Rikets hjelp, genom en naturlig finance-system (i766), ansågs ha kritiserat beslut som ständerna fattat, något som under frihetstiden nästan var jämförbart med ett majestätsbrott. ${ }^{3}$

Som skribent och aktör var Anders Chydenius uttryckligen pragmatiker och han har därför inte heller setts som en teoretiker i egentlig mening. ${ }^{4}$ Chydenius hade till exempel velat trycka en mängd offentligt

3. Pentti Virrankoski, Anders Chydenius. Demokraattinen poliitikko valistuksen vuosisadalta, Porvoo: WSOY I986; Pentti Virrankoski,"Chydenius, Anders", Kansallisbiografia-verkkojulkaisu. Studia Biographica 4, Helsinki: Suomalaisen Kirjallisuuden Seura 1997 (uppdaterad 2012), http://urn.fi/urn:nbn:fi:sks-kbg-002432 (hämtad 28/10 20I8).

4. Se till exempel i Heckscher, "Anders Chydenius"; J.R. Danielson-Kalmari fäller i Suomen valtio- ja ybteiskuntaelämää I8:nnella ja I9:nnella vuosisadalla: Piirteitä vapaudenajalta. 2 Yhteiskunnallisia virtauksia, Porvoo: WSOY ı932, s. 439, följande omdöme om Chydenius: "Hänen suuruutensa ilmenee siinä terävässä älyssä, jolla hän havaitsee mitä edeltäjillä ja aikalaisilla oli parasta hänelle opetukseksi tarjottavana, siinä johdonmukaisuudessa, jolla hän kehittää ja yhdistää eri tahoilta saadut ainekset eheäksi maailmankatsomukseksi." ("Hans storhet framträder i det skarpa intellekt med vilket han urskiljer den bästa lärdom hans föregångare och hans samtida har att erbjuda och i den konsekvens med vilken han utvecklar och kombinerar de byggstenar han erhållit från olika håll till en enhetlig världsåskådning”. Översättning till svenska: MJ). Lars Magnusson i sin tur (Äran, korruptio- 
material, vilket i princip är en vacker tanke men svår att genomföra i praktiken. En sådan verksamhet skulle ha krävt enorma resurser och en stor skara läsare som varit beredda att betala för informationen. Samtidigt kan man fråga sig om Lars Salvius (I706-I773) eller någon annan förläggare i Stockholm hade åtagit sig att trycka Chydenius texter om de inte samtidigt insett vilken potential till goda försäljningssiffror Chydenius fräna stil förde med sig. ${ }^{5}$

I verkligheten kände man dåligt till Chydenius verksamhet och skrifter långt in på r8oo-talet. Nils Erik Forsgård konstaterar att Chydenius framför allt skrev för sin egen referensgrupp, sina jämlikar. En stor del av Chydenius skrifter var inte ens tänkta att hålla för tidens tand; många av dem var pamfletter i häftesformat och trycktes utan pärmar, vilket innebar att de lätt förstördes eller tappades bort. Det är sannolikt av den här orsaken i synnerhet hans politiska skrifter nästan inte alls var kända. Uppgifterna i Tabell I bestyrker åtminstone delvis den här uppfattningen. ${ }^{6}$

Tabell 1. Omnämnanden av Chydenius skrifter i bouppteckningar och protokoll från auktionskamrar i sammanlagt tretton finländska städer före år I8Io. Källa: Databasen Henrik (bttp:// dbgw.finlit.fi/henrik/index.php, hämtad 28/IO 20I8). För exakta bibliografiska uppgifter om texterna, se Chydenius, Samlade skrifter, band ${ }_{I-5}$ och de uppgifter om respektive text som ges där. Alla texter är även tillgängliga på nätet på svenska och finska (bttp://chydenius.kootutteokset. fi/?lang $=$ sv, hämtad 28/3 20I9).

nen och den borgerliga ordningen. Essäer frän svensk ekonomibistoria, Stockholm: Atlantis 20oI, s. 94-95) poängterar att Chydenius inte var helt naiv teoretiskt sett: "[d] et var inte i första hand empirisk kunskap eller common sense som ledde honom fram till hans konsekvent liberala hållning. Den tog istället sin utgångspunkt i en omfattande principiell diskussion som fördes vid denna tidpunkt." Jfr även t.ex. Axel Lille, Anders Chydenius i förhållande till samtida nationalekonomer, Helsingfors: J.C. Frenckell \& Son I882, s. I2I-I22.

5. Virrankoski, Anders Chydenius.

6. Nils Erik Forsgård, Ingens herre, ingens träl. Radikalen Anders Chydenius i I7oo-talets Sverige och Finland, Helsingfors: Schildts \& Söderströms 20I4, s. 3I. 


\begin{tabular}{|c|c|c|c|c|c|}
\hline $\begin{array}{l}\text { Titel (och } \\
\text { utgivningsår) }\end{array}$ & $\begin{array}{l}\text { År då skriften } \\
\text { nämns i } \\
\text { materialet }\end{array}$ & $\begin{array}{l}\text { Försäljare vid } \\
\text { auktionen }\end{array}$ & Köpare & $\begin{array}{l}\text { Person i vars } \\
\text { bouppteckning } \\
\text { skriften nämns }\end{array}$ & Stad \\
\hline $\begin{array}{l}\text { Wederläggning Af } \\
\text { de Skäl, Hwarmed } \\
\text { man söker bestrida } \\
\text { Öster- och } \\
\text { Wästerbotniska } \\
\text { Samt Wäster- } \\
\text { Norrländske } \\
\text { Städerne Fri } \\
\text { Seglation (1765, } \\
62 \text { s.) }\end{array}$ & 1791 & $\begin{array}{l}\text { Skräddar- } \\
\text { mästare } \\
\text { Biörnclo }\end{array}$ & $\begin{array}{l}\text { Guldsmed } \\
\text { Mårten } \\
\text { Fahlström }\end{array}$ & & Helsingfors \\
\hline $\begin{array}{l}\text { Wederläggning Af } \\
\text { de Skäl }\end{array}$ & 1800 & $\begin{array}{l}\text { Herr } \\
\text { Dammert }\end{array}$ & $\begin{array}{l}\text { Hökare Johan } \\
\text { Gustaf Nyman }\end{array}$ & & Helsingfors \\
\hline $\begin{array}{l}\text { Swar på den af } \\
\text { Kgl. Wetenskaps } \\
\text { Academien } \\
\text { förestälta frågan: } \\
\text { Hwad kan vara } \\
\text { orsaken, at sådan } \\
\text { myckenhet swenskt } \\
\text { folk ärligen flytter } \\
\text { utur landet? och } \\
\text { genom bwad } \\
\text { författningar } \\
\text { det kan bäst } \\
\text { förekommas? } \\
\text { (1765, } 104 \text { s.) }\end{array}$ & 1775 & $\begin{array}{l}\text { Överste } \\
\text { Carl David } \\
\text { Blomcreutz }\end{array}$ & $\begin{array}{l}\text { Handelsman } \\
\text { Johan } \\
\text { Sederholm }\end{array}$ & & Helsingfors \\
\hline $\begin{array}{l}\text { Omständeligt Swar, } \\
\text { På Den genom } \\
\text { Trycket utkomne } \\
\text { Wederläggning af } \\
\text { Skriften, Kallad: } \\
\text { Källan til Rikets } \\
\text { Wanmagt, Jämte } \\
\text { Anmärkningar } \\
\text { Öfwer De wid } \\
\text { samma Källa } \\
\text { anstälda Wattu- } \\
\text { Prof. }(1765,168 \text { s.) }\end{array}$ & 1803 & & & $\begin{array}{l}\text { Stadsfogde } \\
\text { Johan Högberg }\end{array}$ & Borgå \\
\hline $\begin{array}{l}\text { Rikets Hjelp, } \\
\text { Genom en Naturlig } \\
\text { Finance-System } \\
(1766,56 \mathrm{~s} .)\end{array}$ & 1780 & & & Sjöman Friberg & Helsingfors \\
\hline Rikets Hjelp & 1790 & $\begin{array}{l}\text { Överste- } \\
\text { löjtnant von } \\
\text { Erichstadt }\end{array}$ & $\begin{array}{l}\text { Kapten } \\
\text { Belzenstjerne }\end{array}$ & & $\begin{array}{l}\text { Sveaborg [sjö- } \\
\text { fästning utanför } \\
\text { Helsingfors] }\end{array}$ \\
\hline Rikets Hjelp & 1794 & & & $\begin{array}{l}\text { Borgmästare } \\
\text { Olof Ramén }\end{array}$ & Torneå \\
\hline
\end{tabular}


Databasen Henrik, i vilken det matats in uppgifter om bokauktioner i finländska städer och bouppteckningar fram till ı8ıo, innehåller endast fyra skrifter av Chydenius och de förekommer där sammanlagt sju gånger. Alla skrifter som omnämns har utkommit 1765-I766, så i de här fallen har skrifterna bevarats i flera årtionden. ${ }^{7}$

I det följande granskar jag den bild som skapats av Chydenius inom finländsk och svensk historieforskning och historieskrivning och hur denna bild har förändrats från I80o-talet fram till 2000-talet. Mindre uppmärksamhet ägnas åt Chydenius egen skriftliga verksamhet, eftersom mitt huvudfokus ligger på den förändring som skett i bilden av Chydenius, på det offentliga historiebruket och på populärhistoriska aspekter. Dessa infallsvinklar har också undersökts i mindre grad, även om antalet verk som behandlar Chydenius i övrigt är påfallande stort.

Artikeln grundar sig i första hand på historieforskares och historieskrivares publikationer samt på digitaliserat finländskt och svenskt tidningsmaterial. Det digitala tidningsmaterialet möjliggör i någon mån även en kvantitativ analys och jämförelser mellan hur känd Chydenius varit under olika tidsperioder i respektive land. Jag inleder ändå med att teckna en allmän bild av bredden i den vetenskapliga litteraturen kring Chydenius.

\section{CHYDENIUS SOM FÖREMÅL FÖR FORSKNING OCH POPULÄRHISTORIA}

De centrala publikationerna om Anders Chydenius från början av I80o-talet till 2oro-talet finns samlade i Tabell 2. Materialet har samlats ur de centrala databaserna och bibliografierna. Vid insamlingen har fokus legat på skrifter som rör Chydenius som person och andra skrifter som direkt rör hans verksamhet. Sannolikt finns det luckor i materialet i de fall där Chydenius figurerat i något annat, mer perifert sammanhang i publikationerna.

Tabellen är uppdelad i två delar så att tabellens övre del ger uppgifter om de centrala publikationstyperna och den nedre delen informa-

7. Under riksdagen I765-1766 och också efter att den avslutats väckte Chydenius skrifter stor uppmärksamhet. En heltäckande bild av dessa skrifter ges bland annat i Virrankoski, Anders Chydenius, och i Chydenius, Samlade skrifter I (2012) och Samlade skrifter 2 (2013). 
tion om hur publikationerna fördelar sig över tid och om publikationer som utkommit i Finland. Endast publikationer som direkt hänvisar till Chydenius har tagits med i urvalet. Uppgifterna är knappast helt fullständiga, men de ger ändå en uppfattning om det verkliga antalet publikationer.

Tabell 2. Publikationer som rör Anders Chydenius I803-20I7. (Verk som utkommit iflera språkversioner och/eller tryckalster som kan klassas som källutgåvor har räknats med bara en gång.) Källor: Suomen Historiallinen Bibliografia 1544-1990, Helsinki: SHS 1940-1992; Svensk historisk bibliografi. Systematisk förteckning öfver skrifter och uppsatser som röra Sveriges historia I77I-I976, Uppsala: Svenska bistoriska föreningen 1875-1985; MELINDA (bttps://melinda. kansalliskirjasto.fl/); ARTO (https://arto.linneanet.fi/); LIBRIS (https://libris.kb.se/).

\begin{tabular}{|l|c|c|}
\hline Typ av publikation & Antal publikationer & $\begin{array}{c}\text { Det sammanlagda antalet } \\
\text { sidor i publikationerna }\end{array}$ \\
\hline Biografi & 32 & 2118 \\
\hline Annan forskning & 62 & 3700 \\
\hline Allmänfattlig framställning & 18 & 77 \\
\hline Källutgåva & 17 & 4005 \\
\hline Sammanlagt & 129 & 10022 \\
\hline Publiceringstidpunkt & & \\
\hline Före år 1929 & 23 & 1661 \\
\hline Åren 1929-2000 & 78 & 3886 \\
\hline Från och med 2001 & 28 & 4475 \\
\hline Publikationer & & \\
\hline utgivna i Finland & 66 & 8632 \\
\hline
\end{tabular}

I sidantal är omfattningen av den forskning som gjorts om Chydenius och den övriga Chydeniusrelaterade utgivningen enorm, sammanlagt över to ooo trycksidor. Nästan 90 procent av den här litteraturen har givits ut i Finland, även om bara cirka hälften av författarna är från Finland. Källutgåvor och andra med dem jämförbara publikationer som innehåller texter av Chydenius bildar den omfångsmässigt största helheten. Den biografiska forskningen och annan forskning kring hans person har också varit livlig. Över tid ser man betydliga förändringar 
i intresset för Chydenius: den första tidsperioden, tiden före I929, sträcker sig över hundra år och avslutas precis innan 200-årsjubileet för Chydenius födelse. Under de följande 70 åren utkom över 2,5 gånger fler publikationer om Chydenius om man ser till sidantalet. Den sista perioden, tiden från millennieskiftet framåt, är i en egen klass, framför allt tack vare utgivningen av Samlade skrifter. Om man ser till bakgrunden hos dem som skrivit om Chydenius märker man att ungefär hälften ${ }^{8}$ av de 65 författarna är professorer eller docenter; med andra ord har Chydenius väckt stort intresse bland forskarna under var och en av tidsperioderna.

Antalet publikationer skulle stiga ytterligare om alla publikationer där Chydenius skrifter använts eller sådana där hans verksamhet ansetts betydelsefull i något avseende medtogs i urvalet. Utgående från det material som forskningsprojektet om finländsk respektive svensk historieskrivning tagit fram är det möjligt att uppskatta att det enbart i Finland har publicerats ett tjugotal avhandlingar där Chydenius roll enligt ovan givna kriterier varit betydande. ${ }^{9}$

\section{Centrala verk om Anders Chydenius och verkens UPPHOVSM ̈̈N}

Enligt Tabell 2 har intresset för Chydenius verksamhet ökat med tiden. Trots detta var Chydenius länge efter sin död en okänd person på båda sidorna om Bottenviken, och hans frånfälle väckte i början ingen

8. Åtminstone följande författare från olika discipliner har gett ut verk som placerar Chydenius i centrum: Aulis J. Alanen, Yrjö J.E. Alanen, Gustaf Björkstrand, J.R. Danielson-Kalmari, Nils Erik Forsgård, Jaakko Gummerus, Leo Harmaja, Eli F. Heckscher, Lars Huldén, Arvid Hultin, O.K. Kilpi, Henrik Knif, Tor Krook, Sakari Kuusi, Jyrki Käkönen, Axel Lille, Lars Magnusson, Juha Manninen, Carola Nordbäck, Gunnar Palander (Suolahti), E. G. Palmén, Hugo E. Pipping, F.J. Rabbe, Kimmo Sarje, Georg Schauman, Erik Rudolf Sjöstrand, Bruno Suviranta, Jakob Tengström, Harald Teir, Carl G. Uhr och Pentti Virrankoski. (Förteckningen kunde göras ännu längre. $\mathrm{Nu}$ tar den inte upp t.ex. alla 2I personer som i Samlade skrifter skrivit kommentartexter och som i sina avhandlingar eller i andra skrifter använt Chydenius texter.)

9. Detta framgår i de databaser projektet Hirsu sammanställt över alla svenska och finländska avhandlingar inom historieämnet. Litteraturförteckningen på Anders Chydenius samlade skrifter-projektets webbsidor ger därtill en bra bild av det inflytande och genomslag Chydenius haft inom olika forskningsdiscipliner, se http://chydenius.kootutteokset.fi/tutkimuskirjallisuus/ (hämtad 28/ro 20I8). 
större uppmärksamhet. Visserligen skrev Jakob Tengström (I755-I832), då professor vid Akademin i Åbo och biskop, sedermera ärkebiskop i Finland, genast 1803 en nekrolog över sin morbror i Allmän Litteraturtidning. ${ }^{10}$

Efter det här skulle det dröja ett halvt sekel innan kyrkoherden i Gamlakarleby på nytt stod i rampljuset. En av de första som lyfte fram Chydenius på nytt var Frans Johan Rabbe (I80I-I879), som var läkare, kamrer vid Överstyrelsen för medicinalverket, en aktiv amatörhistoriker och pionjär inom den finländska biografiska forskningen. År I857 skrev Rabbe en tätt sammanfattad biografisk artikel om Chydenius i verket Finlands minnesvärde män. Den svenska nationalekonomen och bankdirektören Johan Wolter Arnberg (I832-r9oo) lyfte för sin del fram Chydenius som ekonomisk tänkare och debattör i sitt verk Anteckningar om fribetstidens politiska ekonomi publicerat I868. ${ }^{11}$ Nämnda verk recenserades i augusti ${ }^{12}$ samma år i Göteborgs handelsoch sjöfartstidning och i samband med det uppmärksammades även Chydenius. Det liberala Helsingfors Dagblad presenterade de delar av verket som rörde Chydenius synligt på sin första sida bara några veckor senare. Informationen spred sig med andra ord snabbt, vilket till en del berodde på nära kontakter och inbördes släktskap mellan redaktörerna för de båda tidningarna. ${ }^{13}$

Io. Se särskilt Georg Schauman, Biografiska undersökningar om Anders Chydenius jämte otryckta skrifter af Chydenius, Helsingfors: SLS ı908, s. I-8; Virrankoski, Anders Chydenius, s. I3-22; Henrik Knif,"Anders Chydenius”, Rainer Knapas \& Nils Erik Forsgård (toim.), Suomen kulttuuribistoria. Osa 2 Tunne ja tieto, Helsinki: Tammi 2002, s. 7I-75.

II. Johan Wolter Arnberg, Anteckningar om fribetstidens politiska ekonomi. I Handeln och näringarne, Uppsala I868, t.ex. s. 206-215, 243-245.

I2. "Göteborg den 20 Augusti", Göteborgs handels- och sjöfartstidning 20/8 I868; "Göteborg den 28 Augusti", Göteborgs handels- och sjöfartstidning 28/8 I868 (lästa via databasen Svenska dagstidningar, https://tidningar.kb.se/, hämtade 28/ro 2018).

I3. "En av frihetstidens nationalekonomer" del i, Helsingfors Dagblad 4/9 I868; "En av frihetstidens nationalekonomer" del 2, Helsingfors Dagblad 5/9 I868 (lästa via Nationalbibliotekets Digitala samlingar, https://digi.kansalliskirjasto.fi/, hämtade 28/IO 20I8). En av redaktörerna vid Helsingfors Dagblad var i det här skedet Anders Herman Chydenius (1833-I896), som tidigare hade varit redaktör vid Göteborgs handels- och sjöfartstidning. Hans far var Anders Johan Chydenius, vars far i sin tur var Anders Chydenius brorson. Ylioppilasmatrikkeli, https://ylioppilasmatrikkeli. helsinki.fi/henkilo.php?id=I6622, (hämtad 5/9 2019). 
Det var först tack vare professorn i Finlands, Nordens och Rysslands historia Ernst Gustaf Palméns (1849-I9I9) aktivitet som Anders Chydenius viktigaste politiska skrifter slutligen, med början under I870-talet, nådde offentligheten. Palmén hade satt sig in i Chydenius verksamhet redan i sin avhandling, Historisk framställning af den svenskfinska bandelslagstiftningen frän Gustaf Vasas regering till I766 (I876), ${ }^{14}$ och efter det redigerade han i snabb takt två band med Chydenius politiska texter (I877, I880). Därtill skrev han flera publikationer om Chydenius som fick bred spridning. ${ }^{15}$ Ungefär tre decennier efter att Palméns källutgåvor kommit ut fördjupade historikern och bibliotekarien Georg Schauman kunskapen ytterligare genom att publicera Biografiska undersökningar om Anders Chydenius jämte otryckta skrifter af Chydenius (1908), i vilken 500 av 650 sidor utgör en biografi över Chydenius och resten tidigare otryckta skrifter.

Som tabell 3 visar har det efter detta utkommit undersökningar i jämn takt. Forskarna har särskilt fokuserat på Chydenius verksamhet under riksdagen I765-1766, vilket beror på att Chydenius inflytande på ett riksplan var störst just då. Tack vare Palmén och Schauman har ett stort antal av de skrifter som trycktes under Chydenius tid och även de otryckta skrifterna varit tillgängliga för forskarna redan länge. Det är förhållandevis vanligt att forskarna förklarar och vidlyftigt till och med refererar huvudpersonens skrifter, vilket Chydenius originella argumentation och rappa stil ger utmärkta förutsättningar för.

I4. E.G.Palmén, Historisk framställning af den svensk-finska handelslagstiftningen frän Gustaf Vasas regering till I766: akademisk afhandling, Helsingfors: J. C. Frenckell \& Son 1876 .

I5. För en sammanfattning av E.G. Palméns verksamhet som forskare, se särskilt Petri Karonen \& Antti Räihä (toim.), Kansallisten instituutioiden muotoutuminen. Suomalainen historiakuva Oma Maa-kirjasarjassa 19oo-I960, Historiallisia Tutkimuksia 267, Helsinki: SKS 2014 och Matti Klinge, Suomalainen ja eurooppalainen menneisyys. Historiankirjoitus ja historiakulttuuri keisariaikana, Suomalaisen Kirjallisuuden Seuran Toimituksia I285, Tiede, Helsinki: SKS 2010, s. 256-26o. Det är svårt att överskatta betydelsen av Palméns källutgåva, eftersom t.ex. Lille (Anders Chydenius) grundar avsnittet om Chydenius i sin intressanta idéhistoriska jämförelse på de texter Palmén publicerade. 
Tabell 3. Centrala studier och publikationer om Anders Chydenius I803-20I4. Källa: Tabell 2 och de där nämnda källorna.

Tengström, Jacob,"Anders Chydenius", Allmän Litteraturtidning, Åbo: Sällskap i Åbo I803, s. 517-52I.

Rabbe, F.J.,"Chydenius, Anders, prost, riksdagsman, I729-1803”, Finlands minnesvärde män. Samling af lefnadsteckningar, Andra bandet, Helsingfors: J.C. Frenckell \& Son I857.

Arnberg, Johan Wolter, Anteckningar om frihetstidens politiska ekonomi I. Handeln och näringarne, Uppsala 1868.

Palmén, E. G., Politiska skrifter af Anders Chydenius. Med en historisk inledning, I-2, Helsingfors: G.W. Edlunds förlag I877, I88o.

Palmén, E.G., "Antti Chydenius", Biografinen nimikirja. Elämäkertoja Suomen entisiltä ja nykyajoilta, Helsinki: Suomen Historiallinen Seura I879-I883, s. II4-II6.

Lille, Axel, Anders Chydenius i förhållande till samtida nationalekonomer, Helsingfors: J.C. Frenckell \& Son 1882.

Palmén, E. G., Antti Chydenius, Kansanvalistusseuran elämäkertoja 9, Helsinki: Kansanvalistusseura 1903 .

Palmén, E.G.,"Antti Chydenius”, Oma Maa. Tietokirja Suomen kodeille. Osa I, Porvoo: WSOY I907 (andra upplagan I9I9).
Schauman, Georg, Biografiska undersökningar om Anders Chydenius jämte otryckta skrifter af Chydenius, Helsingfors: SLS 1908.

Suolahti, Gunnar, "Chydenius, Antti", Kansallinen Elämäkerrasto. Kansallinen elämäkerrasto I, Porvoo: Helsinki I927, s. 408-4I4.

Heckscher, Eli F., "Anders Chydenius”, Svenskt biografiskt lexikon. Bd 8, CederhielmCornelius, Stockholm: Bonniers I929.

Danielson-Kalmari, J.R., Suomen valtio- ja yhteiskuntaelämää I8:nnella ja I9:nnella vuosisadalla: Piirteitä vapaudenajalta. 2 Yhteiskunnallisia virtauksia, Porvoo: WSOY 1932.

Alanen, Aulis, J., "Pohjanlahden vapaasta purjehduksesta I766-I808. Antti Chydeniuksen elämänsaavutuksen tarkkailua”, Historiallinen Arkisto 53, Helsinki: SHS I950, s. 5-I40.

Krook, Tor, Anders Chydenius. Sambällsreformator och församlingsherde, Arkiv för Svenska Österbotten Io, Helsingfors: Förbundets för svenskt församlingsarbete i Finland bokförlag 1952 .

Uhr, Carl G., Anders Chydenius I729-1803. A Finnish predecessor to Adam Smith, Åbo: Åbo Akademi i963. 
Virrankoski, Pentti, "Anders Chydeniuksen persoonallisuus", Historiallinen Aikakauskirja 8o, I982:I, s. 3-I3.

Sarje, Kimmo, Anders Chydeniuksen liberaali ajattelu ja sen lähteitä, Kokkola: ChydeniusInstituutti 1985 .

Virrankoski, Pentti, Anders Chydenius. Demokraattinen poliitikko valistuksen vuosisadalta, Porvoo: WSOY 1986 (på svenska: Anders Chydenius: demokratisk politiker $i$ upplysningens tid. Översättare Jan-Ivar Lindén och Joachim Mickwitz, Helsingfors: Söderström \& C:O Förlags Ab 1995).

Knif, Henrik, "Anders Chydenius", Rainer Knapas \& Nils Erik Forsgård (toim.), Suomen kulttuuribistoria. Osa 2 Tunne ja tieto, Helsinki: Tammi 2002, s. 7I-75.

Magnusson, Lars, Äran, korruptionen och den borgerliga ordningen. Essäer från svensk ekonomihistoria, Stockholm: Atlantis 2001.

Manninen, Juha, "Anders Chydenius ja maailman ensimmäisen tietämisen vapauden lain synty", Historiallinen Aikakauskirja IO4, 2006:4, s. 470-484.
Nordbäck, Carola, Lycksalighetens källa. Kontextuella närläsningar av Anders Chydenius budordspredikningar, I78I-82, Åbo: Åbo Akademi 2009.

Virrankoski, Pentti, "Chydenius, Anders", Kansallisbiografia-verkkojulkaisu. Studia Biographica 4, Helsinki: Suomalaisen Kirjallisuuden Seura 1997 (uppdaterad 2012) (http://urn.fi/urn:nbn:fi:sks-kbg-002432, hämtad 28/ıo 20I8).

Magnusson, Lars,"Anders Chydenius's Life and Work: An Introduction", Anticipating The Wealth of Nations. The Selected Works of Anders Chydenius (I729-I803). Edited by Maren Jonasson and Pertti Hyttinen. Translated from the original by Peter C. Hogg, London: Routledge 2012.

Forsgård, Nils Erik, Ingens herre, ingens träl. Radikalen Anders Chydenius i I7oo-talets Sverige och Finland, Helsingfors: Schildts \& Söderströms 20I4.

En stor del av de personer som skrivit om Chydenius i olika sammanhang har varit experter inom sitt område eller på den aktuella tidsperioden, och har på det här sättet velat bidra till kunskapsspridningen om Chydenius. På grund av utrymmesbristen kan endast några få av de undersökningar som nämns i ovanstående tabell lyftas fram. 
Under olika tidsperioder har forskarna poängterat och lyft fram olika sidor hos Chydenius. Detta säger dels något om den tid forskaren verkade i, dels något om hans eller hennes värderingar. Frans Johan Rabbe konstaterade i samlingsverket Finlands minnesvärde män. Samling af lefnadsteckningar (1857) att Chydenius:

icke allenast hade följt med sin tid uti framåtsträfvandet till bildning och religionsfrihet, men han var äfven långt framom densamma, och hvad han för nära hundrade år tillbaka öppet förkunnade om frihandel, skråfrihet och religionsfrihet börjar nu vid femtio år efter hans död erkännas såsom solklara sanningar. ${ }^{16}$

Bakom Rabbes tolkning kan man skönja den period av reformer som inleddes i storfurstendömet efter Krimkriget (1853-I856), en period för vilken det var bra att hitta förebilder i gångna tider.

Ernst Gustaf Palméns skrifter om Chydenius, som utkom på svenska och finska, var komprimerade översikter över Chydenius verksamhet, skrivna med lättflytande penna. Matti Klinge har framhävt Palméns aktiva insatser för att lyfta upp Chydenius till en av "nationens hjältar". ${ }^{17}$

Det är lätt att hålla med Klinge, eftersom Palmén är den som på ett individplan gjort mest för att göra Chydenius känd. Palméns betydelse framträder också tydligt till exempel i tidningsmaterialet som behandlas senare i artikeln. ${ }^{18}$ För Palmén var Chydenius ändå inget

I6. F.J. Rabbe, "Chydenius, Anders, prost, riksdagsman, I729-1803", Finlands minnesvärde män. Samling aflefnadsteckningar, Andra bandet, Helsingfors: J.C. Frenckell \& Son I857, s. 321 .

I7. Klinge, Suomalainen ja eurooppalainen menneisyys, s. 259-262; Matti Klinge, A History both Finnish and European: History and the Culture of Historical Writing in Finland during the Imperial Period, The History of Learning and Science in Finland I828-I9I8, n:o I6, [Helsinki]: Societas scientiarum Fennica 20I2, s. 28I-283, 294-296.

I8. Palmén skrev bland annat en biografi över Chydenius. Folkupplysningssällskapet gav ut verket på finska och svenska. Boken var i sig inte särskilt lättfattlig för gemene man, eftersom den först och främst bestod av omfattande referat av Chydenius skrifter och detaljerade beskrivningar av Chydenius verksamhet vid riksdagen I765-I766 i Stockholm. Nästan två tredjedelar av verkets I75 sidor ägnas åt dessa teman. Palmén framställde Chydenius som ett länge bortglömt geni. E. G. Palmén, Antti Chydenius, Kansanvalistusseuran elämäkertoja 9, Helsinki: Kansanvalistusseura I903, se t.ex. s. I67. 
lätt fall att tampas med, eftersom Palmén ofta och i alla sammanhang ville poängtera finskheten och stärka den finska kulturens position. Därtill inföll merparten av Chydenius politiska framgångar under frihetstiden (I718-I772), om vars styrelseskick Palmén hade en mycket negativ uppfattning. Till råga på allt publicerade Chydenius nästan alla sina texter enbart på svenska. Därför var det viktigt för Palmén att framhålla att"släkten Chydenius trots sin främmande namnform var alldeles finsk" och att Chydenius var "en stor fosterlandsvän". ${ }^{19}$

Palmén uppmärksammade särskilt Chydenius insatser för att motarbeta censuren och främja skriv- och tryckfriheten. Då Palmén publicerade sin text genomlevde Finland dystra tider i klorna på den ryska likriktningspolitiken. Palmén motsatte sig häftigt den samtida censuren. Han lyckades skickligt kringgå förhandsgranskningarna och publiceringsförbuden bland annat genom att utge bokserien Oma Maa, som han redigerade, i häften bestående av några tryckark. Palmén tog bland annat i bruk Chydenius I70o-talskritik i en tidig r9oo-talskontext och deltog därmed med tungt vägande inlägg i kampen för att stärka det passiva motståndet. ${ }^{20}$

Redan några år senare gavs publiken en delvis - men uttryckligen bara delvis - annan tolkning än Palméns, i och med att Georg Schauman gav ut sin omfattande biografi över Chydenius. Schauman som var en hängiven anhängare av demokrati poängterade i klar kontrast till Palmén ${ }^{21}$ att Chydenius främjat "frihet och jämlikhet" samt

I9. "Suku Chydenius, nimen vieraasta muodosta huolimatta [oli] aivan suomalainen", "suuri isänmaanystävä". E. G. Palmén, "Antti Chydenius", Oma Maa. Tietokirja Suomen kodeille. Osa I, Porvoo: WSOY I907 (andra upplagan I9I9), s. 400, 4I2. Ifrågavarande text som utkom i den vitt spridda bokserien Oma Maa är en smidigt formulerad sammanfattning av Palméns ovannämnda Chydenius-biografi. Till exempel tidningen Uusmaalainen nämnde ifrågavarande skrift 8/3 1907. Samma text trycktes i åtminstone 25 finskspråkiga tidningar som utkom på olika håll $\mathrm{i}$ landet under de veckor som följde.

20. Palmén, "Antti Chydenius", s. 406. Om Palméns åtgärder för att undvika tidningscensuren, se t.ex. Petri Karonen \& Antti Räihä, "Oma Maa -kirjasarja ja instituutioiden historia", Petri Karonen \& Antti Räihä (toim.), Kansallisten instituutioiden muotoutuminen. Suomalainen historiakuva Oma Maa-kirjasarjassa 190o-I960, Historiallisia Tutkimuksia 267 , Helsinki: SKS 2014, s. 9-28 och den litteratur som nämns där.

2I. Jfr Palmén, Antti Chydenius, s. I7r. Om Palméns kritiska hållning till enkammarriksdagen, se t.ex. Marko Tikka \& Petri Karonen, "Säätyjen edustajat, parlamentarismin puolustajat", Petri Karonen \& Antti Räihä (toim.), Kansallisten 
demokrati. Nämnda värden var enligt författaren ledande tankar i Chydenius skrifter om politik och ekonomi. Således var Chydenius "den moderna demokratins främste föregångare i Sverige och Finland". Även om den andra förryskningsperioden pågick i landet hade Finland redan övergått till enkammarriksdag. ${ }^{22}$ Professorn i finsk historia Pentti Virrankoski (f. 1929) har konstaterat att Schauman identifierade sig med Chydenius och framhävde Chydenius radikalism i sina tolkningar. ${ }^{23}$

Även i nyare verk om Chydenius avslöjar redan rubrikerna författarens huvudpoänger och huvudsakliga tolkningar. Pentti Virrankoski, som till dags dato skrivit den överlägset mest heltäckande och omfattande framställningen där Chydenius placeras in i en rikskontext, talar om en "demokratisk politiker" och för docenten i historia Nils Erik Forsgård (f. I968) framstår Chydenius som radikal. För ekonomhistorikern Lars Magnusson (f. I952) ter sig Chydenius i stället som en anhängare av ekonomisk liberalism, en hållning som också den har långa anor. ${ }^{24}$

instituutioiden muotoutuminen. Suomalainen historiakuva Oma Maa-kirjasarjassa I9oo-I960, Historiallisia Tutkimuksia 267, Helsinki: SKS 20I4, s. 233-234.

22. Schauman, Biografiska undersökningar, s. 484, 490; Pasi Ihalainen har uppmärksammat att Schauman använde liknande formuleringar i riksdagen efter att Finland blivit självständigt. Pasi Ihalainen,"The i8th-Century Traditions of Representation in a New Age of Revolution: History Politics in the Swedish and Finnish Parliaments, I917-I919", Scandinavian Journal of History 2015:I, s. I6, http://dx.doi.org/I 0.1080/03468755.2014.987161.

23. Virrankoski, Anders Chydenius, s. I8-2I.

24. Till exempel Magnusson, Äran, korruptionen och den borgerliga ordningen, s. 8I-96. I nämnda verk hänvisar Magnusson överraskande nog inte alls till Pentti Virrankoskis Chydeniusbiografi som utkom på svenska redan 1995. Saken korrigerades sedermera år 2012 när Magnusson som den första svenska forskaren någonsin använde så gott som all forskning som utkommit om Chydenius i Finland. Lars Magnusson, "Anders Chydenius's Life and Work: An Introduction", Anticipating The Wealth of Nations. The Selected Works of Anders Chydenius (I729-1803). Edited by Maren Jonasson and Pertti Hyttinen. Translated from the original by Peter C. Hogg, London: Routledge 20I2. Andra forskare som skrivit om Chydenius ekonomiska tänkande förutom de redan nämnda är t.ex. Eli F. Heckscher,"Anders Chydenius"; Eli F. Heckscher, Svenskt arbete och liv från medeltiden till nutiden. Med kompletterande tillägg av professor Arthur Montgomery och fil.lic. Bengt Svensson, Stockholm: Bonniers 1957, s. 227 (första utgåvan 194I); Sakari Heikkinen, Visa Heinonen, Antti Kuusterä \& Jukka Pekkarinen, The History of Finnish Economic Thought I809-19I7, The History of Learning and Science in Finland I828-I9I8, I7a, [Helsinki]: Societas scientiarum Fennica 200o, s. 45-46, 52-53. För en idéhistorisk 
Även den ökande spridningen av dagstidningarna och den därigenom breddade offentligheten främjade på ett märkbart sätt medvetenheten om Anders Chydenius verksamhet och gärning. Med vilken hastighet informationen spreds under i86o-talet har nämnts tidigare $i$ artikeln. Den första egentliga biografiska framställningen över Chydenius utkom I864 när den liberala tidningen Helsingfors Posten på tidningens första sida publicerade en ingående presentation skriven av tidningens förläggare och huvudredaktör Theodor Neovius (I833-1886). I texten framhöll Neovius Chydenius roll som frihetens och i allra högsta grad religionsfrihetens förespråkare. Denna upplysta I70o-talspräst, hävdar Neovius,

bidrog kraftigare än någon annan till det första erkännandet af tryckfriheten i Finland och i Sverige [...] för närings- och handelsfrihet [...] [och] med sin klara oförwillade blick insåg han det skadliga i den tidens konstlade och wådliga finanssystem och uppträdde djerft och oförwäget emot detsamma, utan fruktan för konungens eller det rådande partiets misshag $[\ldots] .^{25}$

Därefter går författaren igenom Chydenius mest centrala skrifter. Neovius text innehåller de facto så gott som alla fakta om Chydenius som i regel upprepats i senare framställningar. Huvudredaktörens mod att föra fram uppgifterna på detta frispråkiga och oförtäckta sätt var otypiskt ännu under den här tiden. ${ }^{26}$

Chydenius "stjärna" steg snabbt på den finländska himlen från och med början av följande decennium. En viktig delorsak till detta var att särskilt östfinländska tidningar upprepade gånger skrev om honom. Särskilt de i Viborg utkommande Wiborg och Wiborgs Tid-

tolkning av Chydenius samtid, se särskilt Jouko Nurmiainen, Edistys ja ybteinen hyvä vapaudenajan ruotsalaisessa poliittisessa kielessä, Bibliotheca Historica I22, Helsinki: SKS 2009, till exempel s. 38-40, I30, I53-157.

25. T[heodor]. N[eovius].," En finsk prest för hundra år tillbaka”, Helsingfors Posten I/ıo I864, https://digi.kansalliskirjasto.fi/sanomalehti/binding/450495?page=I (hämtad $4 / 9$ 2019).

26. Om Theodor Neovius, se Ylioppilasmatrikkeli, https://ylioppilasmatrikkeli.helsinki. fi/henkilo.php?id=16803 (hämtad 4/9 2019); jfr Knif,"Anders Chydenius", s. 75 . 
ning utmärkte sig som spridare av information om Chydenius; året I873 var avgörande i detta hänseende. Wiborgs Tidning rapporterade då om en föreläsningsserie som den skickliga amatörhistorikern och språklektorn Gabriel Lagus (I837-I892) hållit och där han konstaterat om Chydenius att denne "är knappast känd i sitt eget fädernesland". Lagus hade tidigare själv varit redaktör för tidningen och senare framhöll han samma sak i sin tidning Östra Finland.I enlighet med gängse kutym kopierade tidningarna artiklar ur andra tidningar och därmed spred sig vetskapen om Chydenius till alla delar av storfurstendömet. Lagus intresse för Chydenius torde ha ett samband både med hans liberala livssyn och hans släktskap med Chydenius. Lagus mor var dotter till redan nämnda ärkebiskop Tengström. ${ }^{27}$

I de bifogade graferna I och 2 har jag med hjälp av Nationalbibliotekets Digitala samlingar kartlagt omnämnanden av Anders Chydenius skrifter i finländsk press från och med året $185 \mathrm{O}^{28}$ fram till 2000-talet. Materialet är approximativt fram till cirka år 1920. Efter den här tidpunkten minskar antalet publikationer som fanns tillgängliga i elektroniskt format när den här artikeln skrevs och samtidigt minskar materialets representativitet betydligt. Med andra ord är materialet inte längre heltäckande efter den här tidsperioden och därför måste uppgiften att noggrannare analysera tidsperioden efter 1920 lämnas åt framtida forskningsinsatser. Som jämförelsematerial har jag valt de (fåtal) omnämnanden av Chydenius som finns i det digitaliserade tidningsmaterialet från Sverige.

För sökningar i det finländska materialet har sökorden "Anders Chydenius" och "Antti Chydenius" använts. Den senare namnformen vann terräng från och med slutet av I8oo-talet när den finskspråkiga

27. Till exempel "Doktor Lagus föreläsning", Wiborgs Tidning 5/4 I873, https://digi. kansalliskirjasto.fi/sanomalehti/binding/464779?page=I (hämtad 4/9 2019);"Hundra år af en hofrätts lif”, Östra Finland I5/5 1876, https://digi.kansalliskirjasto.fi/ sanomalehti/binding/482906?page=I (hämtad 4/9 2019); om Gabriel Lagus, se Ylioppilasmatrikkeli, https://ylioppilasmatrikkeli.helsinki.fi/I853-I899/henkilo. php?id=I736o; Ilmari Heikinheimo, Suomen elämäkerrasto, Helsinki: WSOY 1955, s. 433-434; jfr Virrankoski, Anders Chydenius, s. I8.

28. Det finns endast ett fåtal omnämnanden på svenska och finska i tidningar under tidsperioden före i80o-talets mitt, så de utelämnades från den slutliga analysen. Jfr även t.ex. Virrankoski, "Chydenius, Anders”, Kansallisbiografia-verkkojulkaisu, http://urn.fi/urn:nbn:fi:sks-kbg-002432 (hämtad 28/ıo 20I8). 
tidningspressen växte i omfattning och "förfinskningen" av Chydenius blev allt mer systematisk. ${ }^{29}$ Informationen som ges i graferna är trots detta högst approximativ: en närmare granskning av sökresultaten visar snabbt att det bland sökträffarna finns påfallande många som inte alls knyter an till det tema och den person som är i fokus i den här artikeln. Särskilt den svenskspråkiga namnformen "Anders Chydenius" ger som sökord förutom information som rör kyrkoherden även information om personer som har samma eller nästan samma namn. I den svenskspråkiga pressen förekommer det under den senare hälften av I8oo-talet till och med fyra olika personer som bär namnet Anders Chydenius. ${ }^{30}$ Under i920-talet seglade dessutom motorsegelfartyget Anders Chydenius på världens hav och tidningarna publicerade aktivt uppgifter om fartygets in- och utklarering i hamnarna, liksom tidtabellerna för dess seglingsrutt.

Den här artikeln undersöker främst de absoluta frekvenserna, vilket betyder att sökresultatet inte har relaterats till omfattningen av hela den korpus av tidningsmaterial som använts (den relativa frekvensen) eller att någon direkt jämförelse skulle ha gjorts mellan språken, det vill säga mellan svenskspråkiga respektive finskspråkiga tidningar som skrivit om Chydenius. Uppmärksamhet har naturligtvis ändå fästs vid att volymerna för finsk- respektive svenskspråkiga tidningar förändrades märkbart under undersökningsperioden till de finskspråkigas fördel. I det här sammanhanget har det emellertid varit viktigast att spåra omnämnanden av Chydenius både i svenskspråkiga och finskspråkiga tidningar i Finland. Med andra ord har namnformen i den här kontexten enbart setts som ett instrument för att på ett så heltäckande sätt som möjligt komma åt för ämnet centrala teman och huvudlinjer.

Dessa begränsningar till trots avslöjar sökresultaten att Chydenius fick mer uppmärksamhet i finskspråkig press från och med I89o-talet,

29. Mer exakt har sökorden varit "Antti Chydenius" I och "Anders Chydenius" I. Sökkommandot " I" har använts för att hitta söktermer som ligger så nära varandra som möjligt. Det oaktat har antalet irrelevanta sökträffar varit betydande. En bortgallring av irrelevanta träffar har naturligtvis gjorts med hjälp av en kvalitativ materialanalys, det vill säga en genomläsning av materialet.

3o. Det uppstår lätt en sammanblandning mellan dessa personer. Uppgifterna måste därför alltid kontrollernas i originalet. Jfr t.ex. Heikkinen, Heinonen, Kuusterä \& Pekkarinen, The History of Finnish Economic Thought, s. 244. 
vilket till en del är en följd uttryckligen av det växande antalet tidningar. Klara toppar i intresset infaller naturligt nog under traditionella fest-, märkes- och minnesår. År 1903 när det förflutit hundra år sedan Chydenius död ser man också en tydlig uppgång i antalet biografiska och andra texter som handlar om honom. Skillnaden är förstås uppenbar: vintern 1803 noterades hans bortgång - biskop Tengströms nekrolog undantagen - endast med en nyhetsnotis på ungefär två och en halv rad. ${ }^{31}$

Åren I902-I903 publicerade olika tidningar sammanlagt ett tiotal artiklar av vilka många placerades på tidningens första sida. En annan klar uppgång i det totala antalet artiklar om Chydenius infaller 1929 då det förflutit 200 år sedan Chydenius födelse. Många tidningar rapporterar då om den radierade fest som arrangerades i Helsingfors universitets solennitetssal och där många av tidens främsta akademiker höll anföranden. Samma år utgavs även en finsk översättning av Chydenius politiska skrifter, vilket naturligtvis uppmärksammades på olika sätt i pressen. ${ }^{32}$ Det sista årtal under undersökningsperioden som skiljer sig ur mängden är 1986. Då utkom Pentti Virrankoskis levnadsteckning, vars ställning som den forskningsmässigt mest helgjutna framställningen och auktoritativa biografin fortfarande är ohotad. År I986 publicerades även ett flertal recensioner av Virrankoskis bok samt andra texter som behandlade Chydenius på ett mera allmänt plan; i många av dem "återfick" Chydenius sitt riktiga dopnamn, "Anders", som ersatte det tidigare förfinskade "Antti".

Omnämnanden av Chydenius i sverigesvenska tidningar kartlades på motsvarande sätt som i det finländska materialet. Sökningarna gjordes i databasen Svenska dagstidningar som upprätthålls av Kungliga Biblioteket. En snabb sökning tydde på flera hundra träffar, men en närmare analys visade att den verkliga mängden träffar rörande kyrkoherden var liten och intresset för honom begränsat frånsett de allra senaste åren. ${ }^{33}$ Den största delen av de artiklar och tidningstexter

3I. "Död i Landsorten", Åbo Tidning I2/2 1803, https://digi.kansalliskirjasto.fi/ sanomalehti/binding/4I3964?page=3 (hämtad 6/9 20I9).

32. Till exempel "Anders Chydenius. Tvåhundraårsminnet av hans födelse firas $\mathrm{i}$ dag", Hufvudstadsbladet 26/2 I929, https://digi.kansalliskirjasto.fi/sanomalehti/ binding/r53754r? page=3 (hämtad 6/9 2019).

33. Svenska dagstidningar, databasens användargränssnitt, http://tidningar.kb.se/ (häm- 
som rör Chydenius är generiska texter som har kopierats från tidning till tidning ${ }^{34}$. Det är egentligen först på 2010-talet man i Sverige fäst större uppmärksamhet vid Chydenius verksamhet. Det som skrivits har kretsat kring tryckfrihetsförordningen I766 och dess 250-årsjubileum. ${ }^{35}$ Endast en aning tillspetsat kan man hävda att redan nämnda artikel i Göteborgs handels - och sjöfartstidning 1868 är det första och sista bidraget till en helhetsanalys av Anders Chydenius liv och gärning som den svenska pressen åstadkommit. Det ska samtidigt framhållas att artikeln lade grunden för hela boomen kring Anders Chydenius.

Graf 1. Förekomsten av sökordet "Anders Chydenius" I i fuländsk tidningspress I850-20I0 (N= 2133). Källa: Nationalbibliotekets Digitala samlingar, https://digi.kansalliskirjasto.fl/ (bämtad 28/10 20I8).

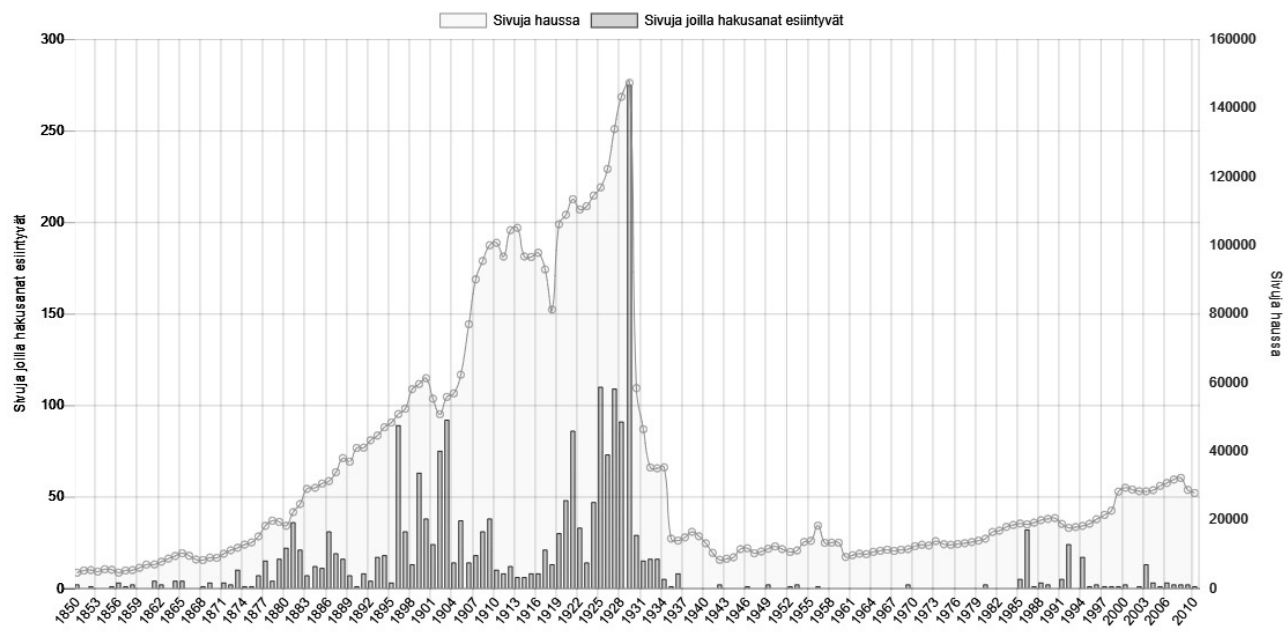

tad 28/ro 20I8). En sökning på frasen"Anders Chydenius" 2 gav sammanlagt 420 sökträffar under tidsperioden I762-20I8. Åren I803-2018 gav 405 sökträffar och åren I850-20I8 sammanlagt 213 träffar. Största delen av träffarna knöt emellertid inte an till Anders Chydenius. I tillägg fanns det ett stort antal dubbla poster.

34. Särskilt i början av den undersökta perioden förekommer det också i de finländska tidningarna denna typ av"vandrande" artiklar, men det var gängse praxis inom den dåtida journalistiken.

35. I anslutning till tryckfrihetsfrågan var Chydenius aldrig en person den så kallade stora allmänheten i Sverige skulle ha känt till. Jfr Forsgård, Ingens herre, ingens träl, s. I8. 
Graf 2. Förekomsten av sökordet "Antti Chydenius" $\sim$ I i finländsk tidningspress åren I850-20I0 $(N=204 I)$. Källa: Nationalbibliotekets Digitala samlingar, https://digi.kansalliskirjasto.fl/ (hämtad $28 / 102018)$.

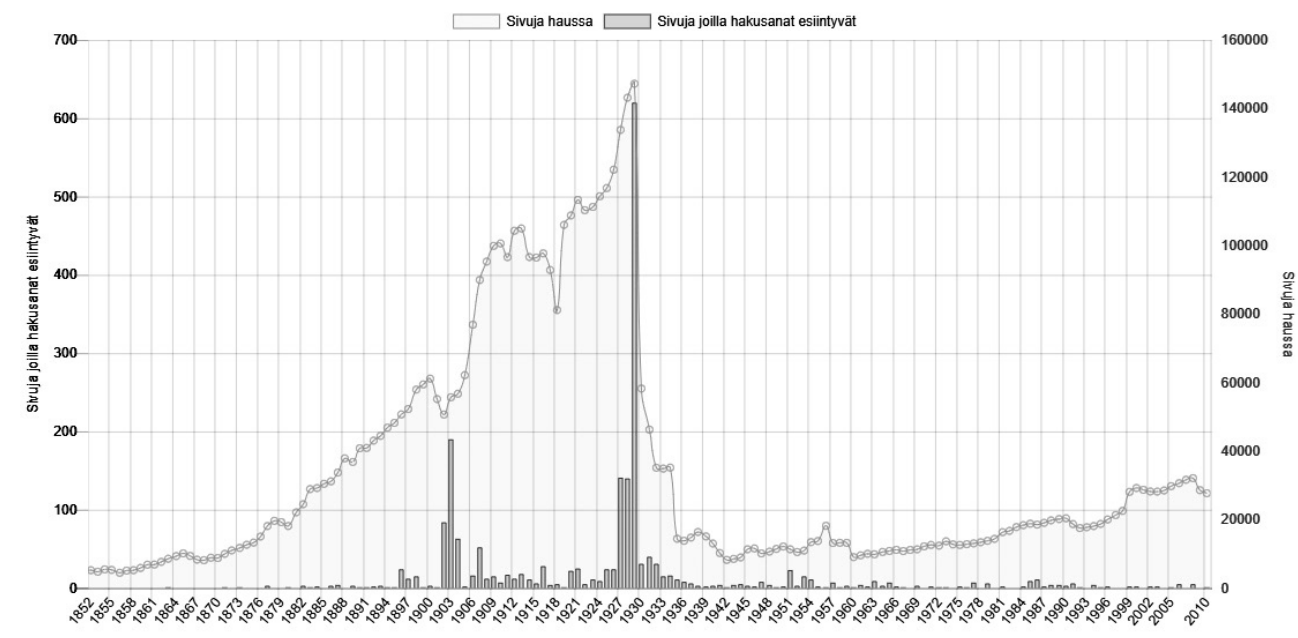

Skalan till höger i graferna ("Sivuja haussa") anger hur många sidor som ingått i sökningen, medan skalan till vänster ("Sivuja joilla hakusanat esiintyvät") anger antalet sidor på vilka sökordet förekommer.

\section{Anders Chydenius betydelse för historie- FORSKNINGEN OCH DEN STORA ALLM ÄNHETEN}

Anders Chydenius har varit en central gestalt i finländsk historieforskning och historieskrivning de senaste 150 åren. Också historiekulturellt har uppskattningen av Chydenius varit betydande; för sina förtjänster har han avbildats bland annat på ett frimärke och på tusenmarkssedeln. För att hedra Chydenius slog man år 2003 även ett jubileumsmynt på tio euro och redan hundra år tidigare restes en minnesstod över honom i Karleby. I Sverige har hans betydelse däremot inte alls varit 
lika stor och särskilt i skrifter riktade till den stora allmänheten har han inte getts någon betydande roll.

Avslutningsvis kan man överväga varför Anders Chydenius framför allt i Finland varit föremål för ett så anmärkningsvärt forskningsintresse. Forskarnas intresse torde först och främst bero på Chydenius mångsidighet. Texterna i Samlade skrifter visar också att Chydenius verksamhet har varit betydande åtminstone inom ämnesområden som politik, ekonomi, teologi, religion, filosofi, medicin och personhistoria. Speciellt för Chydenius var också hans särskilda intresse för att - i motsättning till de då rådande generella normerna i stånds- och privilegiesamhället - utveckla alla områden av riket. ${ }^{36}$ Under den här tiden koncentrerade sig varje aktör i vanliga fall på att främja den egna regionens, referensgruppens eller det egna ståndets intressen. Tack vare sitt klara och modiga framställningssätt i skrift lyckades Chydenius dessutom offentliggöra sina texter. ${ }^{37}$

Många sentida uttolkare av Chydenius texter - forskare och andra som intresserat sig för ämnet - har i Chydenius texter uppfattat gömda eller till och med uppenbara referenser och budskap till forskarens egen tid, vilket lett till att skrifterna använts rätt fritt i de mest skiftande sammanhang. Detta har hänt särskilt i Finland där man i slutet av I80o- och början av I90o-talet upplevde en brytningstid då till exempel de finsksinnade uppnådde ledande ställningar. Det fanns då även ett behov att finna hjältar som passade in i de finsksinnades berättelse. Chydenius var lämplig för denna roll trots att han var svenskspråkig. För den stora allmänheten blev Chydenius en utmärkt förebild i början av I900-talet, under trycket från de ryska myndigheternas likriktningspolitik. Det samtida Sverige saknade helt den här typen av sammanhang och samhälleliga förhållanden. På västra sidan av Bottniska viken var Chydenius tankar därför länge kända nästan enbart inom den akademiska kretsen, mera specifikt inom discipliner som nationalekonomi och ekonomihistoria. Även om svenska historiker intog synliga positioner inom den politiska eliten ännu vid mitten av I900-talet var de betydligt mer dolda för den så kallade stora all-

36. Se till exempel Aulis J. Alanen, Suomen historia vapaudenajalla. Jalmari Jaakkolan johdolla laaditun Suomen historian IX osa, Porvoo: WSOY 1963, s. 566; Virrankoski, Anders Chydenius; Forsgård, Ingens herre, ingens träl, s. I6.

37. Knif,"Anders Chydenius", s. 74 . 
mänheten än sina finländska kolleger. Således uppstod inte heller ett behov eller ett tryck att popularisera den österbottniska kyrkoherdens tankar på samma sätt som i Finland. ${ }^{38}$

Översättning: Maren Jonasson

38. För en noggrannare analys av linjerna i svensk respektive finländsk historieforskning och historieskrivning, se artiklarna och litteraturförteckningarna i verket Petri Karonen (toim.), Tiede ja ybteiskunta. Suomen Historiallinen Seura ja historiantutkimus I80o-luvulta 20I0-luvulle, Suomalaisen Kirjallisuuden Seuran Toimituksia I449, Helsinki: Suomalaisen Kirjallisuuden Seura 2019. 